\title{
TCOM \\ YouTube as a source of information on chloroquine and hydroxychloroquine during the COVID-19 pandemic
}

\section{Thales Brandi Ramos, Luciana Castilho Bokehi, Raphael Castilho Bokehi, Taynah da Silva Pinheiro, Erika Barreto de Oliveira, Renan da Silva Gianoti Torres, José Raphael Bokehi, Sabrina Calil-Elias and Selma Rodrigues de Castilho}

Keywords

DOI

Context
This research aimed to analyze the quality of the information conveyed through YouTube videos in Portuguese on the use of two medicines suggested for the treatment of COVID-19: chloroquine and hydroxychloroquine. The 'Brief DISCERN' questionnaire was applied to assess the quality of the video content as well as baseline characteristics, such as length, views, likes and dislikes, in a total of 90 videos with almost 4,5 million views. Traditional media accounted for $58,89 \%$ of videos. Misleading information was present in most of the videos (63,5\%). Despite the ease of access, the videos showed problems in the quality of information.

Health communication; Science and media; Science communication in the developing world

https://doi.org/10.22323/2.19070206

Submitted: 21st June 2020

Accepted: 17th September 2020

Published: 14th December 2020
The pandemic caused by the new coronavirus, identified as SARS-CoV-2 (Severe Acute Respiratory Syndrome Coronavirus 2), led to an international framework for quarantine and social isolation measures [Centers for Disease Control and Prevention, 2020]. The disease caused by this new virus (COVID-19, as in Coronavirus Disease 2019) accumulates, on August 30 $30^{\text {th }}, 2020$, more than 24 million confirmed cases in the world, with approximately 827 thousand deaths [World Health Organization, 2020]. Brazil declared a public health emergency on February $3^{\text {rd }}$ and up to this date, official reports show over three million cases and 120 thousand deaths [Ministério da Saúde do Brasil, 2020a].

This situation is aggravated by the absence of vaccines and scientifically proven treatments. Some of the most studied drugs have been chloroquine and its 
hydroxychloroquine analog, which were previously prescribed for lupus and rheumatoid arthritis treatments [Esposito, Noviello and Pagliano, 2020]. These drugs had their action against SARS-CoV-2 confirmed in the laboratory after in vitro analyzes at the beginning of the pandemic [Liu et al., 2020; Yao et al., 2020].

Then, the race for results in clinical research brought studies that initially reported an improvement in the clinical condition or a decrease in mortality with the use of chloroquine or hydroxychloroquine [Chen et al., 2020; Colson et al., 2020; Huang et al., 2020], mainly associated with azithromycin [Gautret et al., 2020; Million et al., 2020]. However, these studies had similar limitations: a small number of patients, a lack of randomization, or double-blind design. Still, some studies have shown that the use of these drugs could lead to severe adverse events, such as cardiac arrhythmias due to the prolongation of the QT interval [Mercuro et al., 2020; Tang et al., 2020].

As studies with more extensive sampling and better method definition have been carried out, few benefits from the use of hydroxychloroquine, associated or not with other drugs, have been confirmed [Rosenberg et al., 2020; Tang et al., 2020]. Recently, the U.S. Food and Drug Administration (FDA) canceled permission to use these substances after reviewing international studies claiming that there have been no proven benefits in mortality, in the patient's condition or decreased length of hospitalization [Food and Drug Administration, 2020].

Although these studies are widely disseminated in the scientific community, they do not reach as easily the entire population. The Internet has been identified as a significant source of health-related research, [Rocha Garbin, Faria Pereira Neto and Guilam, 2008; Oliveira, Bertollo-Golloni and Pavarino, 2013; Silvestre et al., 2012] as well as the search for information related to COVID-19 [Bento et al., 2020;

Effenberger et al., 2020; Higgins et al., 2020], even though some social networks and websites increasingly present deficient, incorrect or incomprehensible information [Bastani and Bahrami, 2020; Mian and Khan, 2020; Ramos et al., 2019]. In this scenario, it is up to users and the media to interpret it correctly [Cuan-Baltazar et al., 2020].

The quality of information about medicines on the internet and social networks has been the subject of study of several authors, who have warned of problems in the quality of the information conveyed, which can negatively affect users' decisions about the use of these technologies [Faria Pereira Neto et al., 2017; Sinclair et al., 2017; Al Khaja, AlKhaja and Sequeira, 2018; Ramos et al., 2019].

Al Khaja and colleagues [2018] evaluated the truthfulness of social media claims about drugs and other health-related products, finding that "potentially misleading" claims were the most frequent messages. The authors pointed out that those messages tend to exaggerate efficacy or safety. They concluded that false or potentially misleading claims about drugs on social media lacked good evidence to support them and suggested that regulatory authorities should monitor social media platforms that disseminate health information.

The low quality of information about medications becomes an even more significant problem when this content is not entirely based on evidence about the safety of its use and it must be interpreted cautiously [Hansen et al., 2016]. Gul and 
Diri [2019] found that counterfeit drugs for premature ejaculation were advertised on videos in the composition of sexual performance supplements, with the potential to be a major problem for users' health due to contaminated ingredients and non-sterile manufacturing conditions.

Using the hydroxychloroquine example itself, the preliminary announcement of favorable results in vitro led the population to rush to pharmacies in an excessive and unnecessary purchase of this medicine, resulting in the shortage of the medicine used by patients with other chronic issues [Romano et al., 2020]. Subsequently, in Brazil, the control of this medication was increased, which now requires a special control prescription in two copies, with prescription retention in the establishment, for the dispensation to occur [Conselho Nacional de Saúde, 2020].

The lack of reliable information has led to the indiscriminate use of this medication as a treatment for all degrees of severity of the disease, in addition to its use as prevention. Although there is no scientific evidence to support the use in any of these situations, in several videos the hydroxychloroquine advertisement was reported as a prophylactic measure by the President of the United States of America. There was a $442 \%$ increase in demand for online sales of both hydroxychloroquine and chloroquine after endorsements from these videos [Liu et al., 2020]. Recently, in a preliminary study, researchers indicated that this drug would not affect on post-exposure prophylaxis [Boulware et al., 2020].

In Brazil, approximately $70 \%$ of the population has access to the Internet, and the country ranks fifth concerning the search for health information [Instituto Brasileiro de Geografia e Estatística, 2018]. On the Internet, YouTube has about two billion users, totaling over a billion hours of videos per day [YouTube, 2020]. Brazil has more than 95 million people connected to YouTube. In a survey conducted by the platform itself, 59\% of respondents believe that videos better update them than news on TV programs [YouTube, 2017], which makes the analysis of content in Portuguese important due to the relevance of this network in the dissemination of information.

When searching for videos of health content, more than 190 thousand results are found, mostly related to official agencies and health professionals [Trigo, 2018], with the platform standing out in the search for health information [Duke et al., 2019; Madathil et al., 2014]. The quality of the information specified in videos about medicines has been investigated. The 50 most viewed videos on acne treatment were of low quality, totaling almost 26 million views [Xiang et al., 2020]. A more critical situation was reported when only $3 \%$ of the 133 videos on hip arthritis analyzed were classified as of excellent quality [Koller et al., 2016].

In other epidemics, the quality of information on YouTube has also been assessed. In the pandemic caused by the Zika virus, about $25 \%$ of the videos analyzed had dubious information [Bora et al., 2018], a similar situation was also observed in the H1N1 pandemic [Pandey et al., 2010]. This percentage was even higher (33\%) when analyzing videos during the yellow fever outbreak [Ortiz-Martínez et al., 2017].

Although COVID-19 officially became a global public health risk situation a few months ago, some studies were already published evaluating the quality of 
information about the disease on YouTube [Basch, Hillyer et al., 2020; D'Souza et al., 2020; Khatri et al., 2020; Li et al., 2020; Szmuda et al., 2020]. However, treatment options were not the focus of these studies. Even so, hydroxychloroquine was observed as one of the most discussed subjects in videos on rheumatic disease and COVID-19 [Kocyigit, Akaltun and Sahin, 2020].

Brazil is one of the countries that guides the use of chloroquine and hydroxychloroquine as an early treatment for patients diagnosed with COVID-19 even without scientific evidence to prove its efficacy and safety [Ministério da Saúde do Brasil, 2020b]. Besides encouraging the use, the federal government also intensified its production by the Pharmaceutical Chemical Laboratory from the Armed Forces, with more than 3 million pills already produced [Araújo, 2020]. Also, the press recently announced that the government is considering the inclusion of these products in the list of the Farmácia Popular project, a strategy that seeks to expand the population access to reference drugs for the treatment of diseases such as systemic arterial hypertension and diabetes, through its free distribution in drugstores due to public subsidy [Vargas, 2020].

In a scenario where there are no conclusive studies on the treatment alternatives for COVID-19 and there is a large volume of dubious guidelines being disseminated, it is crucial to evaluate the type of information that Brazilian users of one of the largest Internet platforms have access to.

\section{Objective}

The study aimed to assess the reliability and quality of information on YouTube videos in Brazilian Portuguese on chloroquine and hydroxychloroquine in the context of COVID-19.

\section{Methodology Search protocol}

YouTube research was conducted on May $24^{\text {th }}, 2020$, using the terms 'chloroquine' and 'hydroxychloroquine' combined with 'COVID-19' and 'coronavirus', using the private window and the filter 'relevance' of YouTube's algorithm. The first 50 videos of each search and their URL (uniform resource locators) were selected. The number of videos analyzed was defined based on the proposal of other studies on content analysis on this platform [Basch, Fung et al., 2017; Dubey et al., 2014; Nagpal et al., 2015; Szmuda et al., 2020].

\section{Selection of videos}

Two researchers (TBR and LCB) first analyzed the spreadsheet with hyperlinks, excluding duplicate videos. The following exclusion criteria were applied: duration longer than 15 minutes, since long videos are generally considered less engaging [Guo et al., 2020], content outside the scope of the work and live presentations. Since the study aimed to evaluate the information available on YouTube to the Brazilian population, only videos in Portuguese were considered. 
Descriptive characteristics were duration, the number of views, likes, dislikes, date of publication, and whether the video reports experience of medication use (yes and it does support the use, yes and it does not support the use, or it does not cite the experience of use). The type of YouTube creator covered the following categories: traditional media, health professional, government agency, educational institution, and blogs/websites. All metrics were analyzed on May $28^{\text {th }}, 2020$, as access data changes continuously.

The content analysis was carried out independently by two pairs of evaluators (EBO and TSP, RCB and LCB). Each pair analyzed half of the videos. Each evaluator of the pair analyzed the content independently, and, with a discrepancy between the scores higher than 5 points, a third evaluator (TBR) evaluated that video. The 'Brief DISCERN' was the questionnaire selected to assess the quality of the video content. The instrument is a compact version of the original, used by consumers and health professionals to assess the quality of information on websites [Khazaal et al., 2009]. This version of the questionnaire has been used by several other studies [Bora et al., 2018; Li et al., 2020] and focuses on six questions from the original instrument: references and dates of information, description of treatment, benefits, risks, and effects of the same on the patient's quality of life. Each topic is assessed on a 5-point Likert scale, with 5 being the indicator that the assessment criterion has been met, from 2 to 4 , partially met, and 1 not met (Table 1).

Table 1. The 'brief' DISCERN instrument.

\begin{tabular}{|l|}
\hline \multicolumn{1}{|c|}{ Questions } \\
\hline $\begin{array}{l}\text { 1. Is it clear what sources of information were used to compile the publication (other than } \\
\text { the author or producer)? }\end{array}$ \\
\hline 2. Is it clear when the information used or reported in the publication was produced? \\
\hline 3. Does it describe how each treatment works? \\
\hline 4. Does it describe the benefits of each treatment? \\
\hline 5. Does it describe the risks of each treatment? \\
\hline 6. Does it describe how the treatment choices affect overall quality of life? \\
\hline
\end{tabular}

Question 1 refers to the source of the information, having been assessed based on its clear identification. Score 5 was assigned to videos in which at least one traceable source of information was presented. Scores 2 to 4 were considered when information about the source was not complete or was not traceable. Score 1 was assigned in situations where no information about the source of the information was provided. Question 2 received the highest score if the time of the information production or the last actualization is clearly expressed and the score 1 if it is not informed. Regarding questions 3,5 and 6, the gold standard was the information approved by the National Health Surveillance Agency (ANVISA) for the package leaflet of the products. Thus, for the risk, a score of 5 was considered if the video presented the main contraindications, adverse reactions and precautions described in the package insert and score 1 was assigned if, on the other hand, there was no mention of those aspects. If the information was partially present, the score ranged from 2 to 4 . The same logic was applied in the analysis of the description of the mechanism of action and the possible changes in quality of life-related to each medication. 
An adaptation of the questionnaire was made in the question about treatment benefits. This is because, concerning COVID-19, the drugs chosen in the search had not shown, until the moment of the analysis, conclusive results on the benefits of its use [Rosenberg et al., 2020; Tang et al., 2020]. Therefore, clarifying that the results are still under discussion was considered essential information. Thus, a score of 5 was considered when the video indicated uncertain benefits or pointed benefits but clarifies that they are being studied and they weren't proven yet; 2 to 4 was the score when the video indicated partial benefits and it didn't clarify that those are still being tested; 1 when indicated the cure of the disease through the use of these medications or affirmed the use as a preventive treatment.

\section{Data analysis}

The video's popularity was assessed based on the views and the "likeability" index, which relates the rate of likes by views, with adjustment for the number of dislikes given by the user [Hassona et al., 2016]. Videos with a score equal to or greater than 16 points were considered of good quality evidence (useful) and videos with a score lower than 16 as misleading [Khazaal et al., 2009]. Thus, a video was considered useful if the information presented helps the consumer to make a more conscious decision about the use of these drugs, presenting both the uncertainties about the benefits and the risks involved.

\section{Statistical analysis}

The kappa coefficient was used to assess the degree of agreement between the results of each pair of reviewers and the totality of videos. Descriptive statistics tools were used to analyze the profile of the videos. ANOVA analysis of variance was used to compare the number of views and likeability among the videos considered misleading and useful. Kruskall-Wallis test was used to compare data from the three types of YouTube creators responsible for publishing the most frequent videos, namely, traditional media, blogs/websites, and government agencies. The Pearson $(\mathbb{R}$ ratio coefficient was used to assess the existence of a linear relationship between duration, the number of views, days in the air, likes and dislikes.

\section{Results}

A total of 90 videos were included after the application of the exclusion criteria (Figure 1), representing 5 hours and 5 minutes (mean=00:03:24; $\mathrm{sd}=00: 02: 46$; ranging from 00:00:34 to 00:13:13 minutes); 4.488 .123 views (mean $=49.868$; $\mathrm{sd}=124.232,49$; ranging from 333 to 720.991 views), 140.738 likes (mean=1.581; $\mathrm{sd}=3.613,20$; ranging from 10 to 20.000 likes); 8.642 dislikes (mean=97,10; $\mathrm{sd}=231,78$; ranging from 0 to 1.700 dislikes).

The analysis of the popularity of the videos showed a total viewing rate of $107.224,15$ (mean=336,17; sd=2.259,16; ranging from 9,25 to 15,33), and a likeability index of 298,67 (mean=3,32; sd=2,26; ranging from 0,03 to 15,33). Together, the videos were available for 3.429 days (average $=38,1 ; \mathrm{sd}=23,64$, ranging from 6 to 70 days) (Table 2). In $87,8 \%$ of the videos, the absence of the date of some information provided was identified. In the majority $(58,9 \%)$, no information was identified 


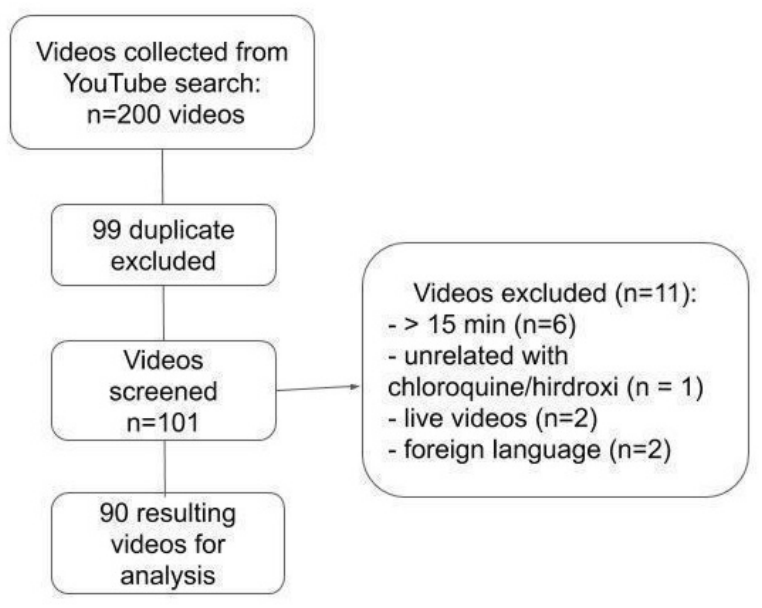

Figure 1. Flowchart of the video selection process for analysis.

regarding the date and in $26(28,9 \%)$ there was the date of only some of the information provided. The mean Brief DISCERN score for all websites was 14,49 out of a maximum score of 30 (ranging from 6 to 24,5).

Table 2. Baseline characteristics of YouTube videos about hydroxychloroquine and chloroquine in the COVID-19 treatment in Brazilian Portuguese.

\begin{tabular}{|c|c|c|c|c|c|}
\hline $\begin{array}{c}\text { Baseline } \\
\text { characteristics }\end{array}$ & Mean & Minimum & Maximum & $\begin{array}{c}\text { Standard } \\
\text { Deviation }\end{array}$ & $\begin{array}{c}\text { Total } \\
\text { Value }\end{array}$ \\
\hline DISCERN Score & 14,49 & 6 & 24,5 & 4,34 & 1304,50 \\
\hline Duration & $00: 03: 24$ & $00: 00: 34$ & $00: 13: 13$ & $00: 02: 46$ & $05: 05: 41$ \\
\hline Number of views & 49.868 & 333 & 720.991 & $124.232,49$ & 4.488 .123 \\
\hline Likes & 1.581 & 10 & 20.000 & $3.613,20$ & 140.738 \\
\hline Dislike & 97,10 & 0 & 1.700 & 231,78 & 8.642 \\
\hline Likeability & 3,32 & 0,03 & 15,33 & 2,26 & 298,67 \\
\hline Number of days online & 38,1 & 6 & 70 & 23,64 & 3.429 \\
\hline
\end{tabular}

Table 3 shows that most videos were uploaded by traditional media $(58,89 \%)$, followed by sites/blogs $(21,11 \%)$ and government agencies $(12,22 \%)$. It is interesting to note that the majority $(75 \%)$ of the videos produced by health professionals, 35,85\% from traditional media, 27,3\% from government agencies and $36,84 \%$ of the blogs/sites were considered useful. As for the popularity of the type of YouTube creator, although representing only $4,4 \%$ of videos, health professionals had the lowest dislikes (median=33,75) and the highest likeability (median=7,18).

The only characteristic that showed a statistically significant difference between the groups responsible for the videos was the number of dislikes $(p=0,04731)$, which was higher for videos from traditional media (median=127,42) and lower for videos from government agencies (median=16,60).

The kappa coefficient of agreement regarding the usefulness classification of the videos was 0,9 (IC $=0,81$ to 0,99 ), considered an almost perfect agreement [Silva and Paes, 2012]. The same situation was observed for the agreement between each pair of evaluators ( 0,80 for EB and TP; 0,90 for RCB and LCB). 
Table 3. Distribution of the general characteristics of YouTube videos about hydroxychloroquine and chloroquine in the COVID-19 treatment in Brazilian Portuguese according to type of YouTube creator.

\begin{tabular}{|c|c|c|c|c|c|c|c|c|c|c|}
\hline & \multicolumn{10}{|c|}{ Type of YouTube creator } \\
\hline & Heal & lth professional & Gover & cnment agency & Trad & ditional media & Educa & tional institution & & tes/blog \\
\hline \multirow{2}{*}{ Videos } & \begin{tabular}{l|l}
$\mathrm{N}$ &
\end{tabular} & $\%$ & $\mathrm{~N}$ & $\%$ & \begin{tabular}{l|l}
$\mathrm{N}$ & \\
\end{tabular} & $\%$ & $\mathrm{~N}$ & $\%$ & $\mathrm{~N}$ & $\%$ \\
\hline & 4 & 4,44 & 11 & 12,22 & 53 & 58,89 & 3 & 3,33 & 19 & 21,11 \\
\hline \multicolumn{11}{|c|}{ Baseline characteristics } \\
\hline - & Total & Mean \pm SD & Total & Mean \pm SD & Total & Mean \pm SD & Total & Mean \pm SD & Total & Mean \pm SD \\
\hline Length & $00: 17: 54$ & $00: 04: 29 \pm 0,0036$ & $00: 21: 46$ & $00: 01: 59 \pm 0,0008$ & 03:10:51 & $00: 03: 36 \pm 0,0018$ & $00: 13: 34$ & 00:04:31 $\pm 0,0039$ & 01:01:36 & $00: 03 \pm 0,002$ \\
\hline Views & \begin{tabular}{|l|}
41.418 \\
\end{tabular} & $10.354,50 \pm 14.136,31$ & 55.184 & $5.017,00 \pm 5872,98$ & 3.906 .943 & \begin{tabular}{|l|}
$73.716,00 \pm 155.142,93$ \\
\end{tabular} & 63.062 & $21.020,67 \pm 35.290,48$ & 421.516 & $22.185 \pm 48.869,1$ \\
\hline Dislike & 135 & $33,75 \pm 44,46$ & 166 & $16,60 \pm 14,92$ & 6.753 & $127,42 \pm 277,40$ & 303 & $101,00 \pm 158,58$ & 1.285 & $67,63 \pm 170,28$ \\
\hline Likeability & 28,73 & $7,18 \pm 6,58$ & 36,91 & $3,36 \pm 2,57$ & 160,19 & $3,02 \pm 1,25$ & 8,06 & $2,69 \pm 1,22$ & 64,78 & $3,41 \pm 2,44$ \\
\hline Days online & 163 & $40,75 \pm 25,60$ & 389 & $35,36 \pm 21,25$ & 2.142 & $40,42 \pm 24,54$ & 159 & $53,00 \pm 16,09$ & 576 & $30,32 \pm 22,65$ \\
\hline \multicolumn{11}{|c|}{ Discern classification } \\
\hline & Useful & Misleading & Useful & Misleading & \begin{tabular}{|l|} 
Useful \\
\end{tabular} & Misleading & Useful & Misleading & Useful & Misleading \\
\hline & $3(75 \%)$ & $1(25 \%)$ & $3(27,3 \%)$ & $8(72,7 \%)$ & $19(35,85 \%)$ & $34(64,15 \%)$ & $1(33,3 \%)$ & $2(66,7 \%)$ & $7(36,84 \%)$ & $12(63,16 \%)$ \\
\hline
\end{tabular}

Only 33 videos (36,67\%) were considered useful: nineteen from traditional media, three from health professionals, three from government agencies; one from an educational institution and seven sites/blogs. Most of the videos considered misleading were published by traditional media (Table 3 ).

The number of views between useful and misleading videos was relatively close, but with a slight predominance for useful videos. An important aspect to be considered is the number of likes for misleading video, relatively higher than for useful videos. Despite this, the number of dislikes was quite close. It should also be considered that useful videos were online on the platform for a few days rather than misleading videos. When comparing the metrics between useful and misleading videos, no characteristics showed a significant statistical difference (Table 4$)$, not even in views $(\mathrm{p}=0,2263)$ or likeability $(\mathrm{p}=0,7391)$.

Table 4. Baseline characteristics of YouTube videos about hydroxychloroquine and chloroquine in the COVID-19 treatment in Brazilian Portuguese according to DISCERN classification.

\begin{tabular}{|c|c|c|c|c|c|c|c|c|c|}
\hline \multicolumn{10}{|c|}{ DISCERN classification } \\
\hline & \multicolumn{4}{|c|}{ Misleading } & \multicolumn{4}{|c|}{ Useful } & \multirow[b]{4}{*}{$\mathrm{p}$-value } \\
\hline \multirow{2}{*}{ Videos } & \multirow{2}{*}{\multicolumn{2}{|c|}{$\frac{\mathrm{N}}{57}$}} & \multicolumn{2}{|c|}{$\%$} & \multicolumn{2}{|r|}{$\mathrm{N}$} & \multicolumn{2}{|c|}{$\%$} & \\
\hline & & & 63 & 33 & & 33 & 36 & 67 & \\
\hline $\begin{array}{c}\text { Baseline } \\
\text { characteristics }\end{array}$ & Total & Mean \pm SD & Min & Max & Total & Mean \pm SD & Min & Max & \\
\hline Length & $02: 57$ & 00:03:07 $\pm 0,0017$ & 00:00:34 & 00:09:48 & 02:08 & $00: 03 \pm 0,0023$ & 00:00:47 & $00: 13: 13$ & - \\
\hline Views & 2.152 .283 & $37.759 \pm 84.815,78$ & 333 & 490.828 & 2.335 .840 & $70.783 \pm 172.115,47$ & 441 & 720.991 & 0,2263 \\
\hline Likes & 71.887 & $1.284 \pm 2.714,26$ & 10 & 15.000 & 68.851 & $2.086 \pm 4.777,16$ & 18 & 20.000 & 0,3072 \\
\hline Dislike & 4.042 & $72,18 \pm 159,65$ & 0 & 841 & 4.600 & $139,39 \pm 317,81$ & 2 & 1.700 & 0,3085 \\
\hline Likeability & 185,68 & $3,26 \pm 2,01$ & 0 & 11,27 & 112,99 & $3,42 \pm 2,65$ & 0,03 & 15,33 & 0,7391 \\
\hline Days online & 2.302 & $40,39 \pm 23,56$ & 6 & 70 & 1.127 & $34,15 \pm 23,62$ & 6 & 69 & 0,4211 \\
\hline
\end{tabular}

Twelve videos, all considered misleading (average score $=8,92$, $\mathrm{sd}=1,52$ ), did not present the source of the information provided. Nine videos, one of which was considered useful, presented case reports to corroborate the use of drugs in the treatment of COVID-19 (average score $=11,5, \mathrm{sd}=3,84$ ). Only one video, classified as useful, used a case report to advise against the use of medications (score $=19,5)$. 
A weak positive linear correlation was observed between the duration of the videos with likes $(\mathrm{r}=0,28 ; \mathrm{p}=0,00008)$, dislikes $(\mathrm{r}=0,16 ; \mathrm{p}=0,00016)$ and number of views $(\mathrm{r}=0,25 ; \mathrm{p}=0,00026)$. The positive correlation between the number of views was strong with likes $(\mathrm{r}=0,97 ; \mathrm{p}=0,0003)$ and moderate with dislikes $(\mathrm{r}=0,61 ; \mathrm{p}=0,0003)$, according to the classification described by Dancey and Reidy [2006].

Analysis of YouTube videos on chloroquine and hydroxychloroquine in the context of the COVID-19 pandemic in Brazil showed a high proportion of content considered misleading, either due to lack of transparency regarding the sources used or the use of incomplete and biased information. Only approximately one-third of the videos were considered useful for users' decision making regarding the treatment of COVID-19. Also, it was found that reliable representatives of science (such as educational institutions and research agencies) represented a little parcel of the sample.

Regarding the quantitative aspects, almost 4,5 million views were found in this study, which is lower than those observed by other authors in videos about COVID-19 [Basch, Hillyer et al., 2020; Li et al., 2020; Khatri et al., 2020]. A possible explanation may be the fact that these studies have included videos produced in English, a language that has a greater global reach, which allows viewing by different populations. In this work, only the videos published in Portuguese and, therefore, easier to access for the Brazilian population were analyzed. It can also be explained by the time window of the pandemic in Brazil, which may have impacted the volume of accesses at the data collection period.

Likewise, as this work only included videos that analyzed the treatment of the disease, it is reasonable to assume that this sample represents only a subset of the total. This smaller number of views was observed by other authors who analyzed only specific subjects of COVID-19, such as Kocyigit and collaborators [2020], in videos on rheumatoid arthritis, and Yuksel and Cakmak [2020], who researched the disease condition related to pregnancy.

The higher frequency of traditional media videos is in line with what is observed in the literature, both in this and other pandemics [Bora et al., 2018; Basch, Hillyer et al., 2020; Khatri et al., 2020; Li et al., 2020]. It is noted that most of these videos were classified as misleading, which was also reported by another study that identified traditional media as the most frequent source and the worst quality of information [Szmuda et al., 2020]. The number of videos published by websites and blogs was observed in similar proportions by other authors [Basch, Basch et al., 2015; Basch, Fung et al., 2017].

The low number of videos posted by health professionals, government agencies, and educational institutions is noteworthy. Despite the lower number of views, most of these videos $(75 \%)$ presented good quality of the content. This is in line with the literature since these sources, generally associated with better results concerning the quality and reliability of information [Sun et al., 2019], have already been observed at low frequencies in other studies [Bora et al., 2018; Dubey et al., 2014; Pathak et al., 2015; Novillo-Ortiz, Hernández-Pérez and Saigí-Rubió, 2017]. Another noteworthy aspect is that the second-highest average of views was from government sources; however, they were the ones with most low-quality 
information. This result contrasts with what was observed in other countries in other pandemics, where government agencies had been identified as trustworthy sources of scientific information [Pandey et al., 2010; Duke et al., 2019]. It may be explained by the controversial position of the Brazilian government, since the Ministry of Health defined a treatment protocol in which indicates the early drug handling of patients diagnosed with COVID-19, as a national action related to the new coronavirus pandemic [Ministério da Saúde. Agência Nacional de Vigilância Sanitária, 2020].

The low representativeness of content creators considered trustable, like health professionals, government agencies, and educational institutions, for example, raises a sign of attention. They need to make better use of digital platforms as a means for the dissemination of reliable videos with evidence-based information [D'Souza et al., 2020; Nagpal et al., 2015]. The use of videos was identified as a mechanism for disseminating scientific information to an audience accustomed to online visual communication [Erviti and Stengler, 2016]. Videos made directly to the Internet have a more exceptional ability to generate views and engagement by users [De Lara, García-Avilés and Revuelta, 2017]. In this scenario, it is worth mentioning that Brazil has a national network of drug information centers, linked to the Ministry of Health, which may represent an interesting strategy for the production of videos with information based on evidence on the rational use of medicines.

There is an unconformity on the quality of the information in videos about COVID-19, as some studies have found it to be useful [D'Souza et al., 2020; Kocyigit, Akaltun and Sahin, 2020], while others showed similar low scores using the same assessment tool [Klila et al., 2013; Banasiak and Meadows-Oliver, 2017] especially in high viewing rates videos [Yuksel and Cakmak, 2020] and in terms of treatment [Szmuda et al., 2020].

In the present study, there was no significant difference between videos considered useful and misleading concerning the views and popularity, which may indicate that, for the population, it is really difficult to identify differences concerning the quality of the information conveyed. Ahmad and Murad [2020] also noted that the population could not differentiate between false and accurate information on social media. However, it has been reported that videos with misleading content were more likely to be viewed, shared, liked, and disliked [Bora et al., 2018]. The most significant number of misleading videos could happen mainly during epidemics, relating this aspect to conspiracy theories, messages that underestimate the severity of the diseases, or that bring false and inconsistent information [D'Souza et al., 2020; Dubey et al., 2014; Ortiz-Martínez et al., 2017; Pandey et al., 2010].

In Brazil, some studies have already analyzed the influence of the country's president's speeches regarding the demand for these medicines on social networks: on Twitter, there was an increase from $8 \%$ to $43 \%$ in fake news after a tweet from the president [Libório et al., 2020] and search peak reaches 100\% on Google Trends after his speeches defending the use of hydroxychloroquine [Lisboa et al., 2020].

It is important to stress the role of social networks in spreading fear and panic about COVID-19, negatively influencing people's mental health and well-being [Ahmad and Murad, 2020]. According to Farooq and colleagues [2020], the 
frequent use of social media could also lead to excessive concern due to the high amount of information. In an analysis of 100 videos about the Zika virus pandemic, traditional media videos were more likely to express anxiety and fear about the virus infection [Basch, Fung et al., 2017]. During the H1N1 epidemic in the United States, the anxiety generated by the situation indicated greater concern with preventive measures, despite also generating unnecessary panic with mental health and product stock [Wheaton et al., 2012].

Education and public engagement are essential for the management of the pandemic, especially concerning public health measures [Basch, Mohlman et al., 2020]. Therefore, it is understood that social media are essential tools for controlling information sharing, especially in relation to changes in behavior in response to the pandemic [Saud, Mashud and Ida, 2020].

Some authors suggest a more direct action by YouTube about the evaluation of the content of their videos, with a clearer demarcation of current and valid information, which would be useful mainly in a pandemic time when the information changes very quickly [Basch, Hillyer et al., 2020] or a message at the beginning of the videos indicating to users the potential for disinformation during these public health emergencies, which would help in recognizing false information [Bora et al., 2018].

The limitations of this study were similar to those found by other researchers who analyzed YouTube videos. First, only videos from one platform were used, not including those published and shared on other social media, such as Facebook, Instagram, Twitter, and WhatsApp, also identified as essential news platforms on the disease [Ahmad and Murad, 2020; Saud, Mashud and Ida, 2020]. Also, as a sectional study, the results refer to the scenario at a specific point in time. Thus, the parameters used to assess the information may change as knowledge about the use of these drugs in COVID-19 is consolidated and in response to public statements of social influencers, like authorities like the president.

To date, the action of chloroquine and hydroxychloroquine against COVID-19 is being studied by several clinical studies conducted around the world. Thus, any evaluation of the content on the Internet about the disease should undergo follow-up studies due to the dynamics and rapidity of the information change. However, the disclosure of the date of production of the information, to allow an adequate evaluation of its content by the population, wasn't observed for the majority of videos analyzed.

If even the scientific community has yet managed to close a concrete definition of the action of these drugs, which source of information can users trust? The longing for an answer, whether about a treatment or vaccine, makes everyone want to reach the definitive answer as quickly as possible. However, the steps of the scientific method need and must be respected, so that the information, when it reaches the general population, is of good quality and reliability.

The communication of evidence-based health information is a significant challenge, especially during a health crisis. Taking into account the amount of false or biased information that is shared and taken for granted nowadays, it is necessary to understand all the complexity that involves the dissemination of scientific 
evidence, identifying the best mechanisms to contribute to health promotion. The use of social media has the effect of bringing research closer to the general population that has never been so attentive in vaccine development processes or clinical studies for new treatment choices like during the COVID-19 pandemic. In a period like this, educating and engaging the population is essential for the adoption of the control and prevention measures proposed by public health specialists. However, only one-third of the videos in the Portuguese language was considered useful in empowering the population in terms of the use of chloroquine and hydroxychloroquine.

The videos on YouTube about a possible treatment for COVID-19 proved to be easy to access and with a high rate of views. However, the information conveyed showed quality problems, which can compromise the efforts of health professionals and public health institutions to deal with the pandemic. The inappropriate use of these drugs is certainly an example of this situation, with the potential of exposing the population to unnecessary risks.

The official protocol for the treatment of COVID-19 in Brazil recommends the use of hydroxychloroquine and chloroquine even in mild cases of the disease. Besides, there are various public demonstrations by the President of the Republic in defense of the use of these drugs, even for prophylaxis. He also disclosed his personal use of chloroquine, when announcing that he tested positive, in July, which has increased the number of videos about these drugs since then. As the majority of those videos contain misleading information, it is reasonable to consider that it may pose a barrier to pandemic control efforts.

Through this study, it is possible to observe the importance of the production and dissemination of evidence-based and high-quality content by educational institutions and health professionals. Today, it is known that it is easy to have information on various subjects on the Internet, but without a guarantee of quality. Therefore, it is necessary for actors such as educational institutions, health institutions and health professionals to understand how to insert themselves in this universe and, in fact, engage in the popularization of scientific information, in such a way that the population has access to secure information, objective and free from any economic or political interests.

References

Ahmad, A. R. and Murad, H. R. (2020). 'The impact of social media on panic during the COVID-19 pandemic in Iraqi Kurdistan: online questionnaire study'. Journal of Medical Internet Research 22 (5), e19556. https://doi .org/10.2196/19556.

Al Khaja, K. A. J., AlKhaja, A. K. and Sequeira, R. P. (2018). ‘Drug information, misinformation and disinformation on social media: a content analysis study'. Journal of Public Health Policy 39 (3), pp. 343-357. https://doi.org/10.1057/s41271-018-0131-2.

Araújo, C. (23rd July 2020). 'Exército já produziu 3 milhões de comprimidos de cloroquina'. UOL.

URL: https://economia.uol.com.br/colunas/carla-araujo/2020/07/23/cor onavirus-cloroquina-exercito-ja-produziu-3-milhoes-comprimidos.htm (visited on 30th August 2020).

Banasiak, N. C. and Meadows-Oliver, M. (2017). 'Evaluating asthma websites using the Brief DISCERN instrument'. Journal of Asthma and Allergy 10, pp. 191-196. https://doi.org/10.2147/jaa.s133536. 
Basch, C. H., Basch, C. E., Ruggles, K. V. and Hammond, R. (2015). 'Coverage of the Ebola virus disease epidemic on YouTube'. Disaster Medicine and Public Health Preparedness 9 (5), pp. 531-535. https://doi.org/10.1017/dmp. 2015.77.

Basch, C. H., Fung, I. C.-H., Hammond, R. N., Blankenship, E. B., Tse, Z. T. H., Fu, K.-W., Ip, P. and Basch, C. E. (2017). 'Zika virus on YouTube: an analysis of english-language video content by source'. Journal of Preventive Medicine and Public Health 50 (2), pp. 133-140. https://doi .org/10.3961/jpmph.16.107.

Basch, C. H., Hillyer, G. C., Meleo-Erwin, Z. C., Jaime, C., Mohlman, J. and Basch, C. E. (2020). 'Preventive behaviors conveyed on YouTube to mitigate transmission of COVID-19: cross-sectional study'. JMIR Public Health and Surveillance 6 (2), e18807. https://doi.org/10.2196/18807.

Basch, C. H., Mohlman, J., Hillyer, G. C. and Garcia, P. (2020). ‘Public health communication in time of crisis: readability of on-line COVID-19 information'. Disaster Medicine and Public Health Preparedness, pp. 1-3. https://doi.org/10.1017/dmp.2020.151.

Bastani, P. and Bahrami, M. A. (2020). 'COVID-19 related misinformation on social media: a qualitative study from Iran'. Journal of Medical Internet Research. https://doi.org/10.2196/18932.

Bento, A. I., Nguyen, T., Wing, C., Lozano-Rojas, F., Ahn, Y.-Y. and Simon, K. (2020). 'Evidence from internet search data shows information-seeking responses to news of local COVID-19 cases'. Proceedings of the National Academy of Sciences 117 (21), pp. 11220-11222. https://doi .org/10.1073/pnas. 2005335117.

Bora, K., Das, D., Barman, B. and Borah, P. (2018). 'Are internet videos useful sources of information during global public health emergencies? A case study of YouTube videos during the 2015-16 Zika virus pandemic'. Pathogens and Global Health 112 (6), pp. 320-328. https://doi.org/10.1080/20477724.2018.1507784.

Boulware, D. R., Pullen, M. F., Bangdiwala, A. S., Pastick, K. A., Lofgren, S. M., Okafor, E. C., Skipper, C. P., Nascene, A. A., Nicol, M. R., Abassi, M., Engen, N. W., Cheng, M. P., LaBar, D., Lother, S. A., MacKenzie, L. J., Drobot, G., Marten, N., Zarychanski, R., Kelly, L. E., Schwartz, I. S., McDonald, E. G., Rajasingham, R., Lee, T. C. and Hullsiek, K. H. (2020). 'A randomized trial of hydroxychloroquine as postexposure prophylaxis for COVID-19'. New England Journal of Medicine 383 (6), pp. 517-525. https://doi.org/10.1056/nejmoa2016638.

Centers for Disease Control and Prevention (2020). Coronavirus disease 2019 (COVID-19) situation summary.

URL: https://www.cdc.gov/coronavirus/2019-ncov/summary.html (visited on 31st May 2020).

Chen, Z., Hu, J., Zhang, Z., Jiang, S., Han, S., Yan, D., Zhuang, R., Hu, B. and Zhang, Z. (2020). 'Efficacy of hydroxychloroquine in patients with COVID-19: results of a randomized clinical trial'. medRxiv. https: //doi.org/10.1101/2020.03.22.20040758. (Visited on 7th June 2020).

Colson, P., Rolain, J.-M., Lagier, J.-C., Brouqui, P. and Raoult, D. (2020). 'Chloroquine and hydroxychloroquine as available weapons to fight COVID-19'. International Journal of Antimicrobial Agents 55 (4), p. 105932. https://doi.org/10.1016/j.ijantimicag.2020.105932.

Conselho Nacional de Saúde (22nd May 2020). Recomendação no 042, de 22 de maio de 2020. Recomenda a suspensão imediata das Orientações do Ministério da Saúde para manuseio medicamentoso precoce de pacientes com diagnóstico da COVID-19, como ação de enfrentamento relacionada à pandemia do novo coronavírus.

URL: http://conselho. saude.gov. br/recomendacoes-cns/1193-recomendaca o-n-042-de-22-de-maio-de-2020 (visited on 16th June 2020). 
Cuan-Baltazar, J. Y., Muñoz-Perez, M. J., Robledo-Vega, C., Pérez-Zepeda, M. F. and Soto-Vega, E. (2020). 'Misinformation of COVID-19 on the internet: infodemiology study'. JMIR Public Health and Surveillance 6 (2), e18444. https://doi.org/10.2196/18444.

D'Souza, R. S., D'Souza, S., Strand, N., Anderson, A., Vogt, M. N. P. and Olatoye, O. (2020). 'YouTube as a source of medical information on the novel coronavirus 2019 disease (COVID-19) pandemic'. Global Public Health 15 (7), pp. 935-942. https://doi.org/10.1080/17441692.2020.1761426.

Dancey, C. and Reidy, J. (2006). Estatística sem matemática para psicologia: usando SPSS para Windows. Porto Alegre, Brazil: Artmed.

De Lara, A., García-Avilés, J. A. and Revuelta, G. (2017). ‘Online video on climate change: a comparison between television and web formats'. JCOM 16 (01), A04. https://doi.org/10.22323/2.16010204. (Visited on 6th June 2020).

Dubey, D., Amritphale, A., Sawhney, A., Dubey, D. and Srivastav, N. (2014). 'Analysis of YouTube as a source of information for West Nile Virus infection'. Clinical Medicine E Research 12 (3-4), pp. 129-132. https://doi.org/10.3121/cmr.2013.1194.

Duke, C. H., Yin, J., Zhang, X., Blankenship, E. B., Akuse, S. E., Shah, G. H., Chan, C.-H., Fu, K.-W., Tse, Z. T. H. and Fung, I. C.-H. (2019). 'Adopting YouTube to promote health: analysis of state health departments'. The Permanente Journal 23 (18), p. 94. https://doi .org/10.7812/tpp/18-094.

Effenberger, M., Kronbichler, A., Shin, J. I., Mayer, G., Tilg, H. and Perco, P. (2020). 'Association of the COVID-19 pandemic with internet search volumes: a Google TrendsTM analysis'. International Journal of Infectious Diseases 95, pp. 192-197. https://doi.org/10.1016/j.ijid.2020.04.033.

Erviti, M. C. and Stengler, E. (2016). ‘Online science videos: an exploratory study with major professional content providers in the United Kingdom'. JCOM 15 (06), A06. https://doi.org/10.22323/2.15060206. (Visited on 31st May 2020).

Esposito, S., Noviello, S. and Pagliano, P. (2020). 'Update on treatment of COVID-19: ongoing studies between promising and disappointing results'. Le Infezioni in Medicina 2, pp. 198-211.

URL: https://www.infezmed.it/media/journal/Vol_28_2_2020_10.pdf.

Faria Pereira Neto, A. de, Paolucci, R., Daumas, R. P. and de Souza, R. V. (2017). 'Avaliação participativa da qualidade da informação de saúde na internet: o caso de sites de dengue'. Ciência E Saúde Coletiva 22 (6), pp. 1955-1968. https://doi.org/10.1590/1413-81232017226.04412016.

Farooq, A., Laato, S. and Islam, A. K. M. N. (2020). 'Impact of online information on self-isolation intention during the COVID-19 pandemic: cross-sectional study'. Journal of Medical Internet Research 22 (5), e19128. https://doi.org/10.2196/19128.

Food and Drug Administration (15th June 2020). Coronavirus (COVID-19) update: FDA revokes emergency use authorization for chloroquine and hydroxychloroquine.

URL: https://www.fda.gov/news-events/press-announcements/coronavirus -covid-19-update-fda-revokes-emergency-use-authorization-chloroquin e-and (visited on 15th June 2020).

Gautret, P., Lagier, J.-C., Parola, P., Hoang, V. T., Meddeb, L., Mailhe, M., Doudier, B., Courjon, J., Giordanengo, V., Vieira, V. E., Dupont, H. T., Honoré, S., Colson, P., Chabrière, E., La Scola, B., Rolain, J.-M., Brouqui, P. and Raoult, D. (2020). 'Hydroxychloroquine and azithromycin as a treatment of COVID-19: results of an open-label non-randomized clinical trial'. International Journal of Antimicrobial Agents 56 (1), p. 105949.

https://doi.org/10.1016/j.ijantimicag. 2020.105949. (Visited on 7th June 2020). 
Gul, M. and Diri, M. A. (2019). 'YouTube as a source of information about premature ejaculation treatment'. The Journal of Sexual Medicine 16 (11), pp. 1734-1740. https://doi.org/10.1016/j.jsxm.2019.08.008.

Guo, J., Yan, X., Li, S., Van der Walt, J., Guan, G. and Mei, L. (2020). 'Quantitative and qualitative analyses of orthodontic-related videos on YouTube'. The Angle Orthodontist 90 (3), pp. 411-418. https://doi.org/10.2319/082019-542.1.

Hansen, C., Interrante, J. D., Ailes, E. C., Frey, M. T., Broussard, C. S., Godoshian, V. J., Lewis, C., Polen, K. N. D., Garcia, A. P. and Gilboa, S. M. (2016). 'Assessment of YouTube videos as a source of information on medication use in pregnancy'. Pharmacoepidemiology and Drug Safety 25 (1), pp. 35-44. https://doi.org/10.1002/pds.3911.

Hassona, Y., Taimeh, D., Marahleh, A. and Scully, C. (2016). 'YouTube as a source of information on mouth (oral) cancer'. Oral Diseases 22 (3), pp. 202-208. https://doi.org/10.1111/odi.12434.

Higgins, T. S., Wu, A. W., Sharma, D., Illing, E. A., Rubel, K. and Ting, J. Y. (2020). 'Correlations of online search engine trends with coronavirus disease (COVID-19) incidence: infodemiology study'. JMIR Public Health and Surveillance 6 (2), e19702. https://doi.org/10.2196/19702.

Huang, M., Tang, T., Pang, P., Li, M., Ma, R., Lu, J., Shu, J., You, Y., Chen, B., Liang, J., Hong, Z., Chen, H., Kong, L., Qin, D., Pei, D., Xia, J., Jiang, S. and Shan, H. (2020). 'Treating COVID-19 with chloroquine'. Journal of Molecular Cell Biology 12 (4), pp. 322-325. https: //doi .org/10.1093/jmcb/mjaa014.

Instituto Brasileiro de Geografia e Estatística (21st February 2018). 'PNAD Contínua TIC 2016: 94,2\% das pessoas que utilizaram a internet o fizeram para trocar mensagens'. IBGE notícias. URL: https: //agenciadenoticias . ibge.gov . br/agencia-sala-de-imprensa/2013-agencia-de-noticias/releases/2007 3-pnad-continua-tic-2016-94-2-das-pessoas-que-utilizaram-a-internet -o-fizeram-para-trocar-mensagens (visited on 17th June 2020).

Khatri, P., Singh, S. R., Belani, N. K., Yeong, Y. L., Lohan, R., Lim, Y. W. and Teo, W. Z. Y. (2020). 'YouTube as source of information on 2019 novel coronavirus outbreak: a cross sectional study of English and Mandarin content'. Travel Medicine and Infectious Disease 35, p. 101636. https://doi.org/10.1016/j.tmaid.2020.101636.

Khazaal, Y., Chatton, A., Cochand, S., Coquard, O., Fernandez, S., Khan, R., Billieux, J. and Zullino, D. (2009). 'Brief DISCERN, six questions for the evaluation of evidence-based content of health-related websites'. Patient Education and Counseling 77 (1), pp. 33-37. https://doi.org/10.1016/j.pec.2009.02.016.

Klila, H., Chatton, A., Zermatten, A., Khan, R., Preisig, M. and Khazaal, Y. (2013). 'Quality of web-based information on obsessive compulsive disorder'. Neuropsychiatric Disease and Treatment 9, pp. 1717-1723. https://doi.org/10.2147/ndt.s49645.

Kocyigit, B. F., Akaltun, M. S. and Sahin, A. R. (2020). 'YouTube as a source of information on COVID-19 and rheumatic disease link'. Clinical Rheumatology 39 (7), pp. 2049-2054. https://doi .org/10.1007/s10067-020-05176-3.

Koller, U., Waldstein, W., Schatz, K.-D. and Windhager, R. (2016). 'YouTube provides irrelevant information for the diagnosis and treatment of hip arthritis'. International Orthopaedics 40 (10), pp. 1995-2002. https://doi.org/10.1007/s00264-016-3174-7.

Li, H. O.-Y., Bailey, A., Huynh, D. and Chan, J. (2020). 'YouTube as a source of information on COVID-19: a pandemic of misinformation?' BMJ Global Health 5 (5), e002604. https://doi .org/10.1136/bmjgh-2020-002604. 
Libório, B., Fávero, B., Dias, T., Ernane, J. and Cavaleiro, C. (26th March 2020). 'Como a desinformação sobre cloroquina se multiplicou no Twitter após aval de Bolsonaro à droga'. Radar Aos Fatos. URL: https://static . aosfatos.org/media /cke_uploads/2020/03/26/radar-01-25mar_uJkNOKK.pdf (visited on 30th August 2020).

Lisboa, L. A., Ferro, J. V. R., Brito, J. R. S. and Lopes, R. V. V. (2020). 'A disseminação da desinformação promovida por líderes estatais na pandemia da COVID-19'. In: Anais do Workshop sobre as Implicações da Computação na Sociedad (WICS 2020). Porto Alegre, Brazil: Sociedade Brasileira de Computação, pp. 114-121. https://doi.org/10.5753/wics.2020.11042.

Liu, M., Caputi, T. L., Dredze, M., Kesselheim, A. S. and Ayers, J. W. (2020). 'Internet searches for unproven COVID-19 therapies in the United States'. JAMA Internal Medicine 180 (8), p. 1116. https://doi.org/10.1001/jamainternmed.2020.1764.

Madathil, K. C., Rivera-Rodriguez, A. J., Greenstein, J. S. and Gramopadhye, A. K. (2014). 'Healthcare information on YouTube: a systematic review'. Health Informatics Journal 21 (3), pp. 173-194. https://doi.org/10.1177/1460458213512220.

Mercuro, N. J., Yen, C. F., Shim, D. J., Maher, T. R., McCoy, C. M., Zimetbaum, P. J. and Gold, H. S. (2020). 'Risk of QT interval prolongation associated with use of hydroxychloroquine with or without concomitant azithromycin among hospitalized patients testing positive for coronavirus disease 2019 (COVID-19)'. JAMA Cardiology 5 (9), p. 1036. https://doi.org/10.1001/jamacardio.2020.1834.

Mian, A. and Khan, S. (2020). 'Coronavirus: the spread of misinformation'. BMC Medicine 18 (1), 89. https://doi .org/10.1186/s12916-020-01556-3.

Million, M., Lagier, J.-C., Gautret, P., Colson, P., Fournier, P.-E., Amrane, S., Hocquart, M., Mailhe, M., Esteves-Vieira, V., Doudier, B., Aubry, C., Correard, F., Giraud-Gatineau, A., Roussel, Y., Berenger, C., Cassir, N., Seng, P., Zandotti, C., Dhiver, C., Ravaux, I., Tomei, C., Eldin, C., Tissot-Dupont, H., Honoré, S., Stein, A., Jacquier, A., Deharo, J.-C., Chabrière, E., Levasseur, A., Fenollar, F., Rolain, J.-M., Obadia, Y., Brouqui, P., Drancourt, M., La Scola, B., Parola, P. and Raoult, D. (2020). 'Early treatment of COVID-19 patients with hydroxychloroquine and azithromycin: a retrospective analysis of 1061 cases in Marseille, France'. Travel Medicine and Infectious Disease 35, p. 101738. https://doi.org/10.1016/j.tmaid.2020.101738.

Ministério da Saúde do Brasil (2020a). Coronavírus painel. URL: https: // covid. saude.gov. br/ (visited on 30th August 2020).

- (2020b). Orientações do Ministério da Saúde para Manuseio Medicamentoso Precoce de Pacientes com Diagnóstico da COVID-19. URL: http: //antigo . saude .gov . br/ima ges/pdf/2020/August/12/COVID-11ago2020-17h16.pdf (visited on 2nd November 2020).

Ministério da Saúde. Agência Nacional de Vigilância Sanitária (23rd March 2020). Resolução RDC no 354, de 23 de março de 2020. Altera a Resolução de Diretoria Colegiada - RDC no 351, de 20 de março de 2020. Diário Oficial da União. URL: http://www . in.gov. br/en/web/dou/-/resolucao-rdc-n-354-de-23-demarco-de-2020-249317430 (visited on 16th June 2020).

Nagpal, S. J. S., Karimianpour, A., Mukhija, D., Mohan, D. and Brateanu, A. (2015). 'YouTube videos as a source of medical information during the Ebola hemorrhagic fever epidemic'. SpringerPlus 4 (1), 457. https://doi.org/10.1186/s40064-015-1251-9. 
Novillo-Ortiz, D., Hernández-Pérez, T. and Saigí-Rubió, F. (2017). 'Availability of information in public health on the internet: an analysis of national health authorities in the Spanish-speaking Latin American and Caribbean countries'. International Journal of Medical Informatics 100, pp. 46-55. https://doi.org/10.1016/j.ijmedinf.2017.01.013.

Oliveira, F., Bertollo-Golloni, E. M. and Pavarino, E. C. (2013). 'A internet como fonte de informação em saúde'. Journal of Health Informatics 5 (3), pp. 98-102. URL: http://www.jhi-sbis.saude.ws/ojs-jhi/index.php/jhi-sbis/article /view/267.

Ortiz-Martínez, Y., González-Ferreira, F., Vega-Useche, L. and Álvarez-Ricardo, M. (2017). 'Is YouTube an accurate and reliable source of yellow fever information during outbreaks?' Travel Medicine and Infectious Disease 18, pp. 73-74. https://doi.org/10.1016/j.tmaid.2017.07.007.

Pandey, A., Patni, N., Singh, M., Sood, A. and Singh, G. (2010). 'YouTube as a source of information on the H1N1 influenza pandemic'. American Journal of Preventive Medicine 38 (3), e1-e3. https://doi .org/10.1016/j . amepre.2009.11.007.

Pathak, R., Poudel, D. R., Karmacharya, P., Pathak, A., Aryal, M. R., Mahmood, M. and Donato, A. A. (2015). 'Youtube as a source of information on Ebola virus disease'. North American Journal of Medical Sciences 7 (7), pp. 306-309. https: //doi.org/10.4103/1947-2714.161244.

Ramos, T. B., Bokehi, L. C., Oliveira, E. B., Gomes, M. S. A., Bokehi, J. R. and Castilho, S. R. (2019). 'Informação sobre benzodiazepínicos: o que a internet nos oferece?' Ciência E Saúde Coletiva.

URL: http://www.cienciaesaudecoletiva.com.br/artigos/informacao-sobr e-benzodiazepinicos-o-que-a-internet-nos-oferece/17218? id=17218 (visited on 13th May 2020).

Rocha Garbin, H. B. da, Faria Pereira Neto, A. de and Guilam, M. C. R. (2008). 'The internet, expert patients and medical practice: an analysis of the literature'. Interface - Comunicação, Saúde, Educação 12 (26), pp. 579-588. https://doi.org/10.1590/s1414-32832008000300010.

Romano, S., Galante, H., Figueira, D., Mendes, Z. and Rodrigues, A. T. (2020). 'Time-trend analysis of medicine sales and shortages during COVID-19 outbreak: data from community pharmacies'. Research in Social and Administrative Pharmacy. https://doi.org/10.1016/j.sapharm. 2020.05.024.

Rosenberg, E. S., Dufort, E. M., Udo, T., Wilberschied, L. A., Kumar, J., Tesoriero, J., Weinberg, P., Kirkwood, J., Muse, A., DeHovitz, J., Blog, D. S., Hutton, B., Holtgrave, D. R. and Zucker, H. A. (2020). 'Association of treatment with hydroxychloroquine or azithromycin with in-hospital mortality in patients with COVID-19 in New York state'. JAMA 323 (24), p. 2493. https://doi.org/10.1001/jama.2020.8630.

Saud, M., Mashud, M. and Ida, R. (2020). ‘Usage of social media in pandemic: seeking support and awareness about COVID-19 through social media platforms'. (Preprint). Journal of Medical Internet Research. https://doi.org/10.2196/preprints.21090.

Silva, R. and Paes, A. (2012). 'Teste de concordância Kappa'. Educação Continuada em Saúde - Einstein 10 (4), pp. 165-166. URL: http://apps . einstein. br/revista/arquivos/PDF/2715-165-166.pdf.

Silvestre, J., Rocha, P., B., S., Cabral, R. and Trevisol, F. (2012). ‘Uso da internet pelos pacientes como fonte de informação em saúde e a sua influência na relação médico-paciente'. Revista da AMRIGS 56 (2), pp. 149-155. 
Sinclair, M., Lagan, B. M., Dolk, H. and McCullough, J. E. M. (2017). 'An assessment of pregnant women's knowledge and use of the internet for medication safety information and purchase'. Journal of Advanced Nursing 74 (1), pp. 137-147. https://doi.org/10.1111/jan.13387.

Sun, Y., Zhang, Y., Gwizdka, J. and Trace, C. B. (2019). 'Consumer evaluation of the quality of online health information: systematic literature review of relevant criteria and indicators'. Journal of Medical Internet Research 21 (5), e12522. https://doi.org/10.2196/12522.

Szmuda, T., Syed, M. T., Singh, A., Ali, S., Özdemir, C. and Słoniewski, P. (2020). 'YouTube as a source of patient information for coronavirus disease (COVID-19): a content-quality and audience engagement analysis'. Reviews in Medical Virology 30 (5), e2132. https://doi .org/10.1002/rmv.2132.

Tang, W., Cao, Z., Han, M., Wang, Z., Chen, J., Sun, W., Wu, Y., Xiao, W., Liu, S., Chen, E., Chen, W., Wang, X., Yang, J., Lin, J., Zhao, Q., Yan, Y., Xie, Z., Li, D., Yang, Y., Liu, L., Qu, J., Ning, G., Shi, G. and Xie, Q. (2020).

'Hydroxychloroquine in patients with mainly mild to moderate coronavirus disease 2019: open label, randomised controlled trial'. BMJ, m1849. https://doi.org/10.1136/bmj.m1849.

Trigo, L. (2018). 'Youtubers da saúde: a informação de saúde sem mediação jornalística'. Comunicação E Inovação 19 (39), pp. 82-96. https://doi.org/10.13037/ci.vol19n39.5031.

Vargas, M. (1st September 2020). 'Ministério discute inclusão de cloroquina no programa Farmácia Popular'. O Estadão.

URL: https://saude . estadao.com.br/noticias/geral, ministerio-discuteinclusao-de-cloroquina-no-programa-farmacia-popular, 70003420649 (visited on 1st September 2020).

Wheaton, M. G., Abramowitz, J. S., Berman, N. C., Fabricant, L. E. and Olatunji, B. O. (2012). 'Psychological predictors of anxiety in response to the H1N1 (swine flu) pandemic'. Cognitive Therapy and Research 36 (3), pp. 210-218. https://doi.org/10.1007/s10608-011-9353-3.

World Health Organization (28th August 2020). Weekly operational update on COVID-19 - 28 August 2020. URL: https://www . who. int/docs/default-sourc e/coronaviruse/situation-reports/wou-28-august-approved.pdf (visited on 30th August 2020).

Xiang, L., Ravichandran, S., Tamashunas, N., Wan, A., Mazmudar, R. S. and Scott, J. F. (2020). 'YouTube as a source of dermatologic information on isotretinoin'. Journal of the American Academy of Dermatology 83 (2), pp. 653-655. https://doi.org/10.1016/j.jaad.2019.12.014.

Yao, X., Ye, F., Zhang, M., Cui, C., Huang, B., Niu, P., Liu, X., Zhao, L., Dong, E., Song, C., Zhan, S., Lu, R., Li, H., Tan, W. and Liu, D. (2020). 'In vitro antiviral activity and projection of optimized dosing design of hydroxychloroquine for the treatment of Severe Acute Respiratory Syndrome CoronaVirus 2 (SARS-CoV-2)'. Clinical Infectious Diseases 71 (15), pp. 732-739. https://doi.org/10.1093/cid/ciaa237.

YouTube (2017). YouTube insights.

URL: https://youtubeinsights. withgoogle.com/introducao (visited on 31st May 2020).

- (2020). YouTube by the numbers. URL: https: //www . youtube. com/yt/about/press/ (visited on 31st May 2020).

Yuksel, B. and Cakmak, K. (2020). 'Healthcare information on YouTube: pregnancy and COVID-19'. International Journal of Gynecology \& Obstetrics 150 (2), pp. 189-193. https://doi.org/10.1002/ijgo.13246. 
Thales Brandi Ramos: Pharmacist, Master's in Administration and Management of Pharmaceutical Assistance from Fluminense Federal University and Ph.D. Student in Sciences Applied to Health Products from Fluminense Federal University.

E-mail: thalesbrandi980@gmail.com.

Luciana Castilho Bokehi: Pharmacist, Resident in Hospital Pharmacy.

E-mail: lubokehi@gmail.com.

Raphael Castilho Bokehi: Medical Student, Voluntary internship at the Center for Supporting Rational Therapy through Information on Medicines (CEATRIM).

E-mail: raphaelbokehi@gmail.com.

Taynah da Silva Pinheiro: Pharmacist, Master's in Administration and Management of Pharmaceutical Assistance from Fluminense Federal University and Ph.D. student in Sciences Applied to Health Products from Fluminense Federal University. E-mail: taynah.pinheiro@live.com.

Erika Barreto de Oliveira: Pharmacist, Resident in Hospital Pharmacy. E-mail: erikabarreto@id.uff.br.

Renan da Silva Gianoti Torres: Pharmacist, Specialist in Hospital Pharmacy, Master in Pharmaceutical Sciences from Federal University of Rio de Janeiro.

E-mail: gianoti_r@hotmail.com.

José Raphael Bokehi: Electronic Engineer, Master and Ph.D. in Biomedical Engineering from the Federal University of Rio de Janeiro.

E-mail: jraphael@ic.uff.br.

Sabrina Calil-Elias: Pharmacist, Master and Ph.D. in Biological Sciences (Pharmacology and Medicinal Chemistry) from Federal University of Rio de Janeiro. E-mail: sabrinacalil@id.uff.br.

Selma Rodrigues de Castilho: Pharmacist, Master and Ph.D. in Biomedical Engineering from Federal University of Rio de Janeiro. E-mail: selmarc@id.uff.br.

\section{How to cite}

Ramos, T. B., Bokehi, L. C., Bokehi, R. C., da Silva Pinheiro, T., Barreto de Oliveira, E., da Silva Gianoti Torres, R., Bokehi, J. R., Calil-Elias, S. and Rodrigues de Castilho, S. (2020). 'YouTube as a source of information on chloroquine and hydroxychloroquine during the COVID-19 pandemic'. JCOM 19 (07), A06. https:/ / doi.org/10.22323/2.19070206. 